Studia Anglica Posnaniensia 47, 2-3, 2012

doi: 10.2478/v10121-012-0004-x

\title{
WHERE BOYS, GIRLS AND CHILDREN COME FROM
}

\author{
BORIS HLEBEC
}

University of Belgrade

\begin{abstract}
The etymology of three very frequent English words child, girl and boy has been notoriously obscure because researchers have failed to pay attention to possible Slavic influence. This article is aimed at rectifying this major oversight by providing abundant evidence of both formal and semantic similarities between the English items and the corresponding Slavic ones and at establishing Scandinavian as an intermediary for girl and boy, no such connector being necessary for child.

\section{1. child}

In the Germanic sphere there are a number of cognates of ModE child $(<\mathrm{OE}$ cild $/ \mathrm{t} \int \mathrm{ild} />/ \mathrm{t} \mathrm{ji}: \mathrm{ld} /$ 'baby' $>$ 'boy or girl, offspring') and colt 'young male of horse; inexperienced person'. The form child bears the greatest similarity to the Gothic noun kilpei 'uterus, womb', while colt is more like OSwed. kulder/kolder > Mod. Swed. kult, kulting 'half-grown animal; boy' and Dan. kuld 'children from the same marriage; litter of animals'. The Gothic nouns kilpei and inkilpo both meaning 'womb' are believed to come from $* k^{w} e l$ - to which the dental suffix was added. The Swedish and Danish forms stem from the expanded IE apophonic variant $* k^{w} o l$ - 'tribe', which also has a reflex in OGr. $k^{h}$ olpos 'womb, vagina' $\left({ }^{*} k^{w} o l-+-p\right)$. All these forms may claim affinity with child on the ground of both form and meaning.

Although the primary meaning 'baby; the unborn or newly born human being; foetus, infant' of OE cild shows its connection with Goth. kilpei, as OED states, child is peculiar to English. It is "[n]ot found elsewhere. In the other WGer. langs its place is taken by kind" (s.v. child). The actual development route and the immediate source of $\mathrm{OE}$ cild have not yet been established.
\end{abstract}


A direct semantic change from 'womb' to 'unborn child', although the two notions are metonymically connected, is questionable, ${ }^{1}$ so we shall try a new tack.

The IE root $* k^{w} e l$ - expanded with $*_{-} d$ occurs also in Slavic languages. Thus, according to SJP and PSR: Pol. czeladź 1. 'servants' 2. (dated) 'journeymen'; biata czeladź 'maid-servants'; czeladnik 1. 'journeyman' 2. (dated) 'servant', czeladzin (dated) 'inmate; servant'; Kashubian (a remnant of Polabian, now a

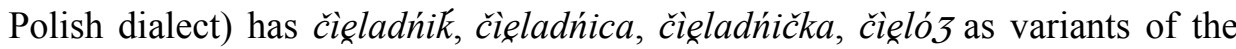
same general meaning (SOB). Slovincian (an extinct variant of Kashubian) had čìeladńǐk 'servant' (LOR) and Russ. челядь ('young inmates' dated usage). In Czech čeled'a means 'young servant; journeyman' and čeled' is 'country servants' or (now obsolete) 'generation, lineage' (CSR). Upper Lusatian has čélédź and Lower Lusatian célaź 'servants' (VASM s.v. челядь). In Lithuanian, a Baltic language, the corresponding noun keltis (or kiltis) denotes generation. It is obvious that formal and semantic closeness to OE cild are greater with the Slavic lexemes than with the Germanic ones mentioned above. ${ }^{2}$

Curiously enough, even Serbian, which is a South Slavic language, bears a great, if not a most relevant, similarity to child both in its current meaning 'offspring' and its obsolete meaning 'young male servant, lad in service' (noted in ME for the first time in 1382, to become obsolete by the beginning of the $17^{\text {th }}$ century). In this language чељљade (čeljade) means 'human creature' (usually 'young'), while the collective чељьad (čeljad) shares the meaning 'house servants, inmates' or 'family' with the corresponding nouns in West Slavic languages.

The suffix -jadb had the meaning of collectiveness couched in the form of grammatical singular, which may have influenced the morphological behaviour of the OE noun cild. Namely, as every student of the English language history knows, cild referred to both one and more than one child. ${ }^{3}$

$1 \quad$ While sentences like How many heads are there in your tribe? or We have to feed a lot of hungry mouths are easily understood because the head and the mouth are permanent parts of the body, it is highly doubtful whether There are a lot of wombs in our village could be interpreted as 'There are a lot of children in our village'. A baby of a pregnant woman is only a temporary resident in her womb, and therefore the attested connection across languages between 'baby' and 'womb' must have been only indirect.

2 Although the Polabian dictionary (LP), which, due to paucity of data contains a limited number of entries, notes only dětę for 'child' and devă or defkă for 'girl' (both common Slavic words), we may safely propose *cel'adb 'young servants' for pre-Polabian, i.e. the same form as for Old Church Slavonic, since similar forms cil'aust 'chin' (Kortlandt 2007) and cel'äust 'doublechin' (VASM s.v. челюсть) have been attested in Polabian, and čìelěsc 'jaw' in Slovinican. In Polabian, according to LP, there also existed the nouns celü 'face, cheek' and cilěsai 'two cheeks'.

3 The meaning 'baby; child' approximately equals the meanings of the following Slavic nouns: OCS čędo, Serb чедo (čedo), Russ. чадо (čado), OPol. czędo, which apparently 
In conclusion, we may surmise a direct influence of *čel'ad' meaning 'young human(s)' in one/some of old West Slavic dialects, on Anglo-Saxon cild at the time when the Angles, Saxons and Jutes were still on the continent, bordering with the Slavs, before their migration to the British Isles. No intermediary is necessary because cild was attested in the earliest OE texts. It has been accepted that Low German shares more features with Balto-Slavic languages than High German, palatalization being one of them (Stanišić 2006: 118), which dovetails into the present proposal.

2. girl

The noun girl had a variety of forms in ME: gurle, gerl, gerle, girle, gyrle, guirle, gierle, gyrll, garle, as well as dialectal gal and gell, which manifests a high instability of the quality of the medial vowel. It has been mentioned in OED that a conjecture favoured by many scholars is that the word represents $\mathrm{OE} *$ gyrela masc., *gyrele fem. from OTeut. *gurwilon (a diminutive of *gurwjo-), akin to Aryan $g h^{w} r g h^{w}$ 'boy, girl'. "This involves some uncertain phonological assumptions, and the late appearance of the Teutonic words gives additional ground for doubt, the ME gürle being recorded only from the end of the $13^{\text {th }} \mathrm{c}$, and the LG gare from the $17^{\text {th }} \mathrm{c}$. It may be noted that boy, lad, lass, and the numerous synonyms in the modern Scandinavian languages are all of difficult etymology; probably most of them arose as jocular transferred uses of words that had originally a different meaning." (OED s.v. girl)

According to MED (s.v. girl), the noun girl may be akin to OE gierela (< *garw-) 'a garment'. According to KLEIN (s.v. girl), the $-l$ in girl is identical with the diminutive suffix $-e l$, but he also considers the word to be of uncertain origin.

The earliest meaning of girl was 'a child or young person of either sex, a youth or maiden', used chiefly in plural (OED s. v. girl). The current meaning 'a female child' appeared only in the middle of the $16^{\text {th }}$ century. When Chaucer in his General Prologue to the Canterbury Tales wrote about the Reeve: "In daunger hadde he at his owene gise / The yonge girles of the diocise", he used the noun girles ambiguously, as it can be interpreted either as 'girls' or 'young people'.

The shortest way to trace girl to its origin would be to propose an OE form descending from Anglo-Saxon. However, this speculation ought to be supported

come from IE *ken- 'beget, bear' > Proto-Slavic čen- 'begotten in the womb' $+d b$. The modern German form Kind 'child' may be associated with the same root, and it had been claimed by some authors that the Slavic forms are loanwords from Germanic, which claim has been eventually rejected (SKOK s.v. čedo, VASM s.v. yado). Although $* k^{w} e l$ - and *ken- are different roots, they are similar in form and meaning, so that some kind of mutual influence cannot be excluded (cf. a similar Sievers' opinion stated in OED s.v. child). 
by an $\mathrm{OE}$ recorded form, which is missing. A less direct way would be to surmise an OE uncharted form borrowed from an (also uncharted) Scandinavian one in the $9^{\text {th }}$ or $10^{\text {th }}$ century. We are inclined to find the latter solution more probable as it is well known that "[m]ost of the Scandinavian words in OE do not actually occur in written records until the ME period, though there can of course be no doubt of their currency long before the beginning of this period" (Pyles 1964: 332). "As we examine the record of borrowing from Scandinavian it is very important to remember that we come to know of it only when English texts appear in Scandinavianised areas, or from place-names, which in these areas are often recorded long after they must have come into use" (Strang 1970: 255). It was only when literacy developed in the northern and eastern parts of England that the strong Scandinavian influence became obvious. As De Caluwé-Dor has stated, "[i]t is common practice for historians of the English language to stress the exceptional character of the Scandinavian borrowings in English. [...] They lament the lack of documents and sources. They argue that the first documents are evidently later than the first uses of the words. Then they comment on the different strata of Scandinavian loan-words and the probability that these loans might have been considered as colloquial or even vulgar long before becoming standard English" (De Caluwé-Dor 1979: 680).

Along the same lines we are going to seek the origin of girl in a Scandinavian loan word coming ultimately from a West Slavic dialect. The word most likely to have originated $g i r l$ is $*_{\text {grb }}(d) l o$.

Slavic and Baltic variants corresponding to girl also show a variety of forms for the accented vowel: Ukr. and Bulg. горло (gorlo), ORuss. and Bulg. гърло (gъrlo), OCS grъlo, Serb gрло (grlo), Slovene grlo, Ruthenian horlo, Lithuanian gurklys (all meaning 'throat' or 'larynx').

The etymon of these lexemes must have been Proto-Slavic *gzrdlo because some present-day variants of grblo contain $d$ of the morpheme -dlo, which is definitely a Slavic suffix: Pol. gardto, Czech and Slovak. hrdlo, ULus. hordto, LLus. gjardto. Slovincian, which is nearer to Germanic in space has garlo, without $d$ (LOR), while the Old-Polish Dictionary (SS) has gardto besides garto, with an additional metaphoric meaning 'life'. Old Prussian, which is a Baltic language, had gurcle. The by necessity limited Polabian dictionary (LP) does not contain a correspondent of $* g$ grdlo. However, after consulting it and having found in it saidlü 'awl' for Pol. szydło, Czech šidlo, Slovak. šidlo, ULus. šidto, LLus. šydto, Kash. šëdto and rådlü for Pol. and Lus. radto and Czech radlo 'hookplough', all with $d$, where Russian, Bulgarian, Serbian, Ukrainian, and Slovenian have шило (silo) and рало (ralo) respectively, i.e. without $d$, we are inclined to believe that (pre-)Polabian, like its historical neighbours, had preserved $d$ in the corresponding word. Thus it remains as a moot question whether Old Norse, as a predecessor of modern Scandinavian languages, 
adopted $*_{g}$ zrdlo or $*_{g}$ brlo. If the Slavic donor contained $d$, which is more likely, this consonant must have been dropped somewhere during its subsequent history in Old Norse and OE. Phonotactic rules in English do not prohibit the $r d l$ sequence, as attested by words such as girdle, curdle and hurdle. It might be the case that the very existence of girdle 'belt' had brought about the loss of $d$ in *girdle 'girl' in order to avoid a homophonic clash. The loss could have also been brought about by the great frequency of its use, so that further reduction issued in some dialects, leading to gal.

Now the question of meaning. The throat is a vital body part, since blocking the passage through the windpipe leads to death. Old Polish and Old Czech reflected this fact by the polysemy: gardlo and hrdlo respectively for 1. 'throat' 2. 'life'. It is well known that parts of the body can stand metonymically for the person (cf. in English: hand, head, heart. mouth, as in Shut up, you big mouth! All hands on board! lazy bones). Thus Old Serbian established the polysemy gрьло (grblo) 1. 'throat' 2.'person' (RMS, ISJ s. v. gрло). In present-day Serbian gрло (grlo) is still currently used for an individual head of cattle, usually a horse, and occasionally for an individual fowl (RSKNJ). The meaning 'person' was especially frequent in the prepositional phrase по герьлу (ро gerblu) 'per head' (DAN s.v. грьло). The meaning 'a child of either sex' of ME girl (with its variants) and Low German göre comes as quite expected if we follow the proposed etymology from *grdlo 'person; animal' in some West Slavic dialects in the past. Moreover, OED records the meaning of girl 'a roebuck in its second year' which has become obsolete by 1726 , which closely parallels the use of grlo for animals in Serbian.

\section{3. boy}

About the etymology of boy imaginative tales have been told. According to KLEIN, boy is related to the OE personal name Böfa, OFris. böfa 'boy, a young gentleman', MDutch boeve, Mod. Dutch boef /bu:f/ 'knave, villain', the Old High German personal name Buobo, MHG bube 'boy'. A similar account has been offered in OED, which underlines its obscure origin, adding EFris. boi, boy 'young gentleman' as the same word. When trying to clarify the etymological connection of boy with personal names, it should be mentioned that while it is not impossible for a common noun to originate from a personal name (cf. Pol. król, Russ. король (korol'), Serb краљь (kralj) 'king' < Kar(a)l; Pol. cesarz, Russ. uapb (car'), Serb uap (car) 'emperor' < Cæsar), it is usually the name of an eminent person that is the source. Furthermore, the personal name itself is usually derived from another common noun. Therefore, it is more realistic to look for the origin of Böfa and Buobo in a common noun denoting a young man, than vice versa. 
SOED tells an even more fanciful story proposing Latin boia 'fetter' as a possible origin of boy: "Early var[iant]s point to an AFr*abuié, *embuié [...] pa[st] $\mathrm{p}$ [artici]ple of OFr embuier fetter: - late L[atin] *imboiare f[rom] in $\mathrm{IM}^{-1}+\mathrm{L}$ boia $\mathrm{pl}[\mathrm{ural}]$ boice fetters". The underlying reason for deriving boy from a word meaning 'fetter' probably lay in the secondary meaning of boy, which is 'servant, slave'.

In Slavic languages there are a lot of nouns derived from Common Slavic bojъ 'fight' with the meaning 'fighter': Serb бојаник (bojanik), бојаи (bojac), бојник (bojnik), бојанија (bojanija dialectal), бојаниија (bojandžija, with the Turkish suffix -uиja) , ${ }^{4}$ Russ. бoeuz, OCS bojbcb, Czech bojovnik, Pol. bojowiec and bojownik 'fighter', as well as bojówka 'group of fighters' and the adjective bojowy 'fighting'. SJP has only boj 'battle' and SLAW has bait meaning 'beat', while there is no such a word as boj in SOB, but we can safely posit the existence of a similar corresponding noun with the meaning 'fighter' in West Slavic dialects in the past.

According to Vasmer, the male personal name Bojan probably comes from bоjь (VASM s.v. Боян). Bojan was also a name of a place on the island of Fehmarn (nowadays lying in the German part of the Baltic Sea which borders with Denmark), inhabited by the Slavs till $12^{\text {th }}$ c. Some other place names on the same island are also Slavic male proper names (Dragan, Tešimir, Ratmir, Badimir; cf. Vukcevich 2001: Ch. XXI, 2).

All Germanic variants mentioned in KLEIN (Böfa, böfa, boeve, boef, Buobo, $B u b e$ ) contain a bilabial plosive followed by a rounded high vowel and a labial postvocalic consonant, which leads us back to a contracted form of an old variant of bojowiec and bojownik as the most probable source. Thus *bojow- > *bow, *boi might have produced both the proper names and the ME common noun boi.

The first group of words that entered OE from Scandinavian was connected with war, like cnear 'small warship', scegpmann 'pirate', dreng 'warrior', orrest 'battle', ran 'robbery'. This means that war was an early semantic 'centre of expansion' (Sperber's term in Ullmann 1964: 201). Therefore it is not surprising if we look for the origin of boy in the sphere of war, bearing in mind that warriors were mainly young men. It is also known that the OE noun beorn at first meant 'warrior' to become generalized as 'man' subsequently. OE nouns hoelep and rinc shared the polysemy of 'man', 'hero' and 'fighter'. In fact, '[...]

Admittedly, this is also the case with its near-synonym offspring. The suffix $-r u$ was added later on analogy with lambru (= lambs) and cealfru (= calves), and subsequently even this was expanded by -en to produce the Mod.E children. The Serbian noun boj 'battle' has yielded Hungarian baj and Romanian razboinic 'warrior' comes from Serb разбојник (razboj-nik) 'plunderer'. The noun bojan mentioned in SJP meaning 'old Slavic poet and roaming singer' or 'Slavic fairy-tales teller' is of a different root. 
a large number of panchronic near-synonyms of man [in OE] have been derived by interpreting mutual spaces from the conceptual domain WARRIOR/SOLDIER and the conceptual domain MAN|MALE HUMAN BEING" (Grygiel 2008: 130).

A similar semantic connection between 'fighter' and 'man', but in the opposite direction, is shown in the OE noun guma, whose meanings 'warrior' and 'hero' are secondary to the earlier sense 'man' (Grygiel 2008: 139). Likewise, the Serbian lexeme јунак (junak), which nowadays means 'hero', formerly referred to a young man (and is still used dialectally in that meaning), and in Russian, молодеи (molodec) 'young man' has added the meaning 'hero'.

Another English word from this group, lad, is redolent of the Ukrainian noun lado 'husband', while its cognate лада (lada) in Old Russian meant 'husband', in Old Czech 'girl', in Ukranian and Serbian 'wife'. The Proto-Slavic goddess of love was named Lada, which is, according to Miklošič (quoted in SKOK s.v. lado) connected with laska ('love' in Czech). Now, the English noun lass 'girl; sweetheart' has been a product of lask (according to SOED s. v. lass), which gives support to the present etymological proposal. By all probability, boy and girl, like lad and lass nowadays, were dialectal forms existing in OE in parallel with cnafa 'boy', magu 'young man; son' and mag(e) $b^{\text {' } g i r l ' .}$

The secondary meaning of boy in English 'slave, servant' could be easily explained as derived from 'warrior' $>$ 'captive', which indicates the same course of borrowing as mentioned here.

\section{Conclusion}

The general historical background to the phenomena proposed here can be easily established. At the time suspected for the language contacts as delineated here, the Danes and Saxons bordered with the Slavs, who dominated a vast territory. It was only natural that they influenced each other. For example, to mention only a random choice of quotations from history books, it is said that the Danish king Godfred destroyed the Obodrite ${ }^{5}$ market at Reric and established a trading town at Hedeby c. 808 (Holman (2010: xi). "The German settlers were driven out of Denmark in 983 by an alliance consisting of Obodrite soldiers and troops loyal to Harald [I, the Danish king]" (Forte et al. 2005). Elsewhere it has been mentioned that Sven I, the Danish king lead the Danes and Slavs against the English and Norwegians in 1010. Danes fought against Polabian Slavs in the 1147 Wendish crusade. "The king of Denmark is well known as an ally especially of Polabian Slavs. [...] Danish policy towards the Slavs was probably more complex, and

5 The Obodrites were a West Slavic tribe bordering with the Danes. They may have originated from the Balkans because there existed a tribe with the same name in the Balkans. 
alongside temporary alignments, there were probably also times of conflict" (Morawiec 2006: 708). The name of Berlin comes from Polabian berl or birl 'bog' and quite many other names of places in Germany and Austria are of Slavic origin, like Leipzig < Lipic, Leibnitz < lipbnica, Graz < Gradec, Dobritzschen < Dobricin, Ferschnitz < *berzbnica, Edlitz < jedlica, Fladnitz $<*$ *blatbnica, Pettog $<$ potokb, Dollnitz < dolinica (cf. Popović 1960: Ch. 3 )

The German expansion into the East happened only later. "Before the thirteenth century there were very few German towns beyond the Elbe, although German traders established themselves in the most important Slav centres. Later it was not uncommon for an old Slav centre to be refounded as a German city" (Angold - Dobson 1970: 20).

\title{
REFERENCES
}

\author{
Angold, Michael - Barrie Dobson \\ 1970 The world of the Middle Ages. New York - London - Toronto - Sidney: Hamlyn \\ De Caluwé-Dor, Juliette \\ 1979 "The chronology of the Scandinavian loan-words in the Katherine Group", English \\ Studies 60/6: 680-685 \\ Grygiel, Marcin \\ 2000 From semantic change to conceptual blending. Semantic development of English \\ historical near-synonyms of man/male human being. Rzeszów: Uniwersytet \\ Rzeszowski. \\ Popović, Ivan \\ 1960 Geschichte der serbocroatischen Sprache. Wiesbaden: Otto Harrassowitz. \\ Pyles, Thomas \\ 1964 The origins and development of the English language. New York: Harcourt, Brace \& \\ World. \\ Stanišić, Vanja \\ 2006 Увод у индоевропску филологију [Introduction to Indo-European Philology] Bel- \\ Strang, Barbara \\ grade: Cìgoja Štampa. \\ 1970 A history of English. London: Methuen. \\ Ullmann, Stephen \\ Vukcevich, Ivo \\ Semantics: An introduction to the science of meaning. Oxford: Basil Blackwell. \\ 2001 Rex germanorum - populos sclavorum. Santa Barbara, CA: University Center Press.
}

\section{INTERNET SOURCES}

Forte, Angelo - Richard Oram - Frederik Pedersen

Viking Empires. Cambridge: Cambridge University Press. $<$ http.//wn.com/Harold I of Denmark> (date of access: Nov. 2011). 
Holman, Katherine

2010 Historical Dictionary of the Vikings.

$<$ http://www.cultorweb.com/ebooks/storia/Historical\%20of\%20the\%20Vikings.pdf $>$ (date of access: Nov. 2011).

Kortlandt, Frederik

2007 "Polabian accentuation" <www. kortlandt. al/publications/art 107e.pdf $>$ (date of access: Aug 2010).

Mckinnell, John - David Ashurst - Donata Kick (eds.)

The fantastic in Old Norse/Icelandic literature: Sagas and the British Isles. Preprint Papers of the Thirteenth International Saga Conference. Durham: The centre for Medieval and Renaissance Studies.

Morawiec, Jakub

2006 "Vinða myrðir, Vinðum háttr. Viking raids on the territory of Slavs in the light of skaldic poetry”, in: Mckinnell et al. (eds), 707-717, <http://www.dur.ac.uk/medieval $>$ $<$ www/sagfaconf/morawiec $>$ (date of access September 2010).

\section{DICTIONARIES}

Češko-srpski rečnik [A Czech-Serbian Dictionary]. (CSR)

2001 Belgrade: Zavod za Udžbenike i Nastavna Sredstva.

Daničić, Đura (DAN)

[1863-1864]

1975 Рјечник из књижевних старина српских [A Dictionary of Words fromSerbian Klein, Ernest (KLEIN) Literary Antiquities]. Belgrade: Vuk Karadžić.

1966 A Comprehensive Etymological Dictionary of the English Language. Amsterdam London - New York: Elsevier.

Kurath, H. (ed.) (MED)

1956 Middle English Dictionary. Ann Arbor: University of Michigan Press.

Lehr-Spławiński, Tadeusz - Kazimierz Polański (LP I)

1962 Stownik etymologiczny języka Drzewian połabskich [Etymological Dictionary of the Old Polabians] fasc. I. Wrocław - Kraków - Warszawa: Polska Akademia Nauk.

Lehr-Spławiński, Tadeusz - Kazimierz Polański (LP II)

1971 Stownik etymologiczny języka drzewain połabskich fasc.II. Wrocław - Kraków Warszawa: Polska Akademia Nauk.

Lorentz, Friedrich (LOR)

Slovinzisches Wörterbuch [A Slovincian Dictionary] I . St. Petersburg: Kaiserlichen Akademie der Wissenschaften.

Oxford English Dictionary ( $2^{\text {nd }}$ ed.) (OED)

1989 Oxford: Oxford University Press.

Poljsko-srpski rečnik/ Stownik polsko-serbski [Polish-Serbian dictionary] (PSR)

1999 Belgrade: SANU - Zavod za Udžbenike i Nastavna Sredstva.

Речник српскохрватског књижевног и народног језика [Dictionary of the Serbo-Croatian Standard and Vernacular Language] (RSKNJ)

1959-2006 Belgrade: SANU. 
Shorter Oxford English Dictionary. (SOED)

1973 Oxford: Clarendon press.

Skok, Petar (SKOK)

1971-1974 Etimologijski rječnik hrvatskoga ili srpskoga jezika [An Etymological Dictionary of the Croatian or Serbian Language]. Zagreb: JAZU.

Sławski, Franciszek (SLAW)

1952-1982 Stownik etymologiczny języka polskiego. [Etymological Dictionary of the Polish Language] Kraków: Nakładem Towarzystwa Miłośników Języka Polskiego.

Stownik języka polskiego [A Dictionary of the Polish Language] (SJP)

1958 Vol. I (A - Ć) \& II (D - G) Warszawa: Polska Akademia Nauk.

Stownik prastowiański [Proto-Slavic Dictionary] Vol. VIII Gode - Gyža (SP)

2001 Wroclaw - Warszawa - Kraków: Zakład Narodowy im. Ossolińskich/ Wydawnictwo Polskiej Akademii Nauk.

Stownik staropolski [Old Polish Dictionary] II Da - Dobrowolny (SS)

1956 Wroclaw - Kraków - Warszawa: Polska Akademia Nauk: SOW.

Sobierajski, Zenon (ed.) (SOB)

1997 Stownik gwarowy tzw. Stowinców kaszubskich [A Dialectal Dictionary of the socalled Kashubian Slovincians] Vol. I A -C. Warszawa: Polska Akademia Nauk/ Instytut Slawistyki.

Vasmer, Max (VASM)

1986 Этимологический словарь русского языка [Etymological Dictionary of the Russian Language]. Moscow: Progress. 